\title{
Study of Chlamydiae in patients with lymphogranuloma venereum and urethritis attending a venereal diseases clinic
}

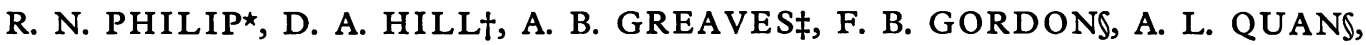 \\ R. K. GERLOFF*, AND L. A. THOMAS*
}

From the Rocky Mountain Laboratory ${ }^{\star}$ and the Laboratory of Infectious Diseasest, National Institute of Allergy and Infectious Diseases, National Institutes of Health, Department of Health, Education, and Welfare, Hamilton, Montana, and Bethesda, Maryland; the Venereal Disease Control Division $\ddagger$, District of Columbia Department of Health, Washington, D.C.; and the Naval Medical Research InstituteS, Bethesda, Maryland, U.S.A.

Interest in the role of trachoma-inclusion conjunctivitis (TRIC) Chlamydiae in urogenital infection was aroused by the reports of British investigators (Jones, Al-Hussaini, and Dunlop, 1964; Al-Hussaini, Jones, and Dunlop, 1964; Dunlop, Jones, and AlHussaini, 1964). It is now known that these organisms are common sources of infection, but their causal relationship to diseases such as nongonococcal urethritis (NGU) and postgonococcal urethritis (PGU), although suggestive, has not yet been firmly established.

Lymphogranuloma venereum (LGV) Chlamydiae have been differentiated from TRIC strains only by their greater pathogenicity in certain experimental systems, particularly laboratory mice. Schachter and Meyer (1969) questioned the reliability of this criterion for differentiation in some instances. Two of their recent LGV isolates from servicemen and seamen returning from South-east Asia were avirulent for mice, and had these strains not been recovered from buboes, they would have been considered as TRIC Chlamydiae.

Although LGV has been reported infrequently in the United States during the last two decades, the District of Columbia has long been a locus of high incidence. In fact, 46 per cent. of all LGV cases reported to the National Communicable Disease Center from 1962 to 1967 occurred in Washington, D.C.

Received for publication October 5, 1970

Supported in part by the Bureau of Medicine and Surgery, U.S. Department of the Navy, Research Task MF12.524.009.1007B.

The opinions or assertions contained herein are those of the authors and are not to be construed as official or reflecting the views of the Navy Department or the naval service at large.

Please address correspondence and requests for reprints to Dr. R. N. Philip, Rocky Mountain Laboratory, Hamilton, Montana 59840, U.S.A.
(W. J. Brown, Chief, Venereal Disease Branch, personal communication). The high incidence there is partly due to greater interest in and better reporting of LGV by health authorities than occurs in most areas.

Since NGU is also prevalent, the District of Columbia (D.C.) seemed to us to be a good area for recovery of TRIC as well as LGV Chlamydiae circulating in the same population group. This study was undertaken to obtain and compare LGV and TRIC strains and to acquire additional information on chlamydial infections in patients with urethritis. It was recognized that the latter objective would be handicapped by the absence of a suitable control group. However, it was hoped that use of sensitive procedures to isolate Chlamydiae, irradiated McCoy-cell culture, and the determination of serological responses to infection by the radioisotope precipitation (RIP) test would provide useful clues. The results of the study are reported below. The association of mycoplasmas with urethritis was also investigated and is the subject of a companion paper (Hill, Philip, Greaves, and Purcell, in preparation).

\section{Material and Methods}

The study was conducted for 2 months in the autumn of 1968 at the Northwest Central Venereal Disease Clinic, which is one of two venereal disease clinics serving D.C. The daily clinic attendance ranges from 90 to 120 patients. Roughly 70 per cent. have gonorrhoea and 5 per cent. have NGU or PGU. Syphilis and LGV cases are seen less frequently. The characteristics of the clinic population have been described more fully in previous publications (Greaves and Taggart, 1953; Greaves, 1963).

\section{STUDY POPULATION}

The 155 participants in the study were patients or their sexual contacts from whom specimens were obtained either for isolation of Chlamydiae or for serological study. 
Diagnosed by four experienced physicians, they included twelve patients with typical LGV, nine with questionable LGV, 36 with NGU, eleven with PGU, 59 with gonorrhoea, and thirteen with primary or secondary syphilis. Six sexual contacts of LGV patients and nine contacts of NGU cases were also included.

All LGV suspects attending the clinic were participants. Although Frei and complement-fixation (CF) tests were routine procedures, the diagnosis of LGV was primarily clinical. Typical cases included ten with fluctuant buboes and two with ano-rectal disease. Questionable cases had either cutaneous lesions of the genitalia or nonfluctuant inguinal adenopathy, or both. Several also had syphilis or gonorrhoea. All LGV patients were males.

Participants with NGU, PGU, gonorrhoea, and syphilis were selected at random from the male clinic population for study as the laboratory work-load permitted. NGU was diagnosed on the basis of a urethral discharge which was negative for gonococci on microscopic examination of Gram-stained smears. Cultures were not routinely obtained. Participants with PGU had persistent or recurrent NGU after penicillin treatment for gonorrhoea. Diagnosis of syphilis was confirmed by the results of serum tests or by darkfield examination. The contacts of LGV and NGU cases were females with few or no symptoms. However, most had mucopurulent cervical discharge and one had a Bartholin's cyst.

\section{SPECIMEN COLLECTION}

Specimens for isolation of Chlamydiae were obtained from buboes and from the urethra in cases of LGV, from the urethra in cases of NGU, PGU, and gonorrhoea, and from the cervix and urethra in contacts of NGU and LGV. Isolation was usually attempted only from untreated patients except for the penicillin-treated cases of PGU. It had been hoped that urethral and cervical specimens could be obtained with Dunlop-Jones curettes (Dunlop and others, 1964), but this was not feasible in this population group, and bacteriological loops and cotton-tipped applicators moistened in saline were used to collect exudate and epithelial cells from the cervical os and from up to $4 \mathrm{~cm}$. beyond the urethral meatus. Microscopical examination for intracellular inclusions was not attempted.

All specimens were held and transported at $4^{\circ} \mathrm{C}$. in vials containing $2 \mathrm{ml}$. veal infusion broth with 0.5 per cent. bovine serum albumin (VIB). Within $6 \mathrm{hrs}$ each specimen was subdivided into four parts:

(a) $0.5 \mathrm{ml}$. was diluted with $1.5 \mathrm{ml}$. sucrose-potassiumglutamate (SPG) containing $10 \mathrm{mg}$. streptomycin, $4 \mathrm{mg}$. vancomycin, and $1 \mathrm{mg}$. neomycin, for primary isolation of Chlamydiae in embryonated eggs;

(b) $0.5 \mathrm{ml}$. was added to $1.5 \mathrm{ml}$. VIB for isolation of mycoplasmas;

(c) $0.5 \mathrm{ml}$. was added to $0.5 \mathrm{ml} .0 .4 \mathrm{M}$ sucrose-phosphate, $\mathrm{pH} 7 \cdot 1$, and held at $-60^{\circ} \mathrm{C}$. for primary isolation of Chlamydiae in irradiated McCoy cells;

(d) $0.5 \mathrm{ml}$. was stored at $-60^{\circ} \mathrm{C}$. for reference purposes.

Blood samples were obtained from nearly all participants during their initial visit and again 2 to 4 weeks later from one-third of the patients who returned to the clinic for this purpose. The sera were tested for CF, RIP, and neutralizing $(\mathrm{SN})$ antibodies.

\section{YOLK SAC CULTURE}

$0.5 \mathrm{ml}$. of the 1:4-diluted specimen was promptly injected into the yolk sacs of four 4- to 6-day embryonated eggs from antibiotic-free chickens. Embryos were incubated at $35^{\circ} \mathrm{C}$. until the 14th or 15th day after inoculation. The yolk sacs from all surviving embryos, as well as from those dying after the 4th day, were examined microscopically for elementary bodies and passed to additional eggs as 10 per cent. suspensions in SPG. Four blind passages were made before an isolation attempt was considered negative. Serial passages of normal yolk sac to monitor crossinfection were uniformly negative for Chlamydiae.

IRRADIATED CELL CULTURE

Cell culture procedures were those previously described (Gordon, Harper, Quan, Treharne, Dwyer, and Garland, 1969). Monolayers for inoculation were derived from $120,000 \mathrm{McCoy}$ cells irradiated with 4,000 to $5,000 \mathrm{r}$ seeded on coverslips in 1-dram vials. To minimize crosscontamination, specimens were processed individually under two alternately-used hoods which were ventilate and decontaminated with 5 per cent. lysol and ultravioled light after each use.

The aliquot for cell culture was diluted in $4.0 \mathrm{mi}$ culture medium (CMGA). $1.25 \mathrm{ml}$. of this final $1: 10$ dilution was transferred to each of four vials of irradiated cells. After centrifugation at 1,600 G. for $1 \mathrm{hr}$, the inoculum was replaced with $1.0 \mathrm{ml}$. fresh CMGA. After $48 \mathrm{hrs}$ ' incubation at $35^{\circ} \mathrm{C}$., two cultures were examined for glycogen-containing inclusions at a magnification of $200 \times$. The inclusions in sixty microscopic fields were counted if one or more were seen in each field. The whole coverslip was examined if no inclusions or only a few were present. The remaining two cultures were passed at $\mathbf{7 2}$ hrs at $1: 2$ or $1: 5$ dilutions in CMGA.

On the second passage, if inclusions were seen at $48 \mathrm{hrs}$ in two cultures, the other two were harvested at $72 \mathrm{hrs}$. If inclusions were not found in any of the four cultures, the isolation attempt was considered to be negative. All positive harvests from the second or subsequent passages were mixed with equal parts of $0.4 \mathrm{M}$ sucrose-phosphate and stored at $-70^{\circ} \mathrm{C}$. in $1 \mathrm{ml}$. aliquots.

CF TEST

Ether-soluble acetone-extracted chlamydial group antigens were prepared according to the method of Hilleman and Nigg (1948) from the agent of enzootic abortion of ewes (OA) (Stamp, McEwen, Watt, and Nisbet, 1950) and from the first LGV strain isolated by yolk sac inoculation in this study (DC-009). All sera were tested simultaneously in 2-fold dilutions from $1: 8$ to $1: 512$ against both antigens according to a procedure previously described (Philip, Lackman, Frank, Morrison, Casper, and Greaves, 1967). The patterns of serum reactivity to both antigens were similar. However, since the test against $\mathrm{OA}$ was slightly more sensitive, the CF results against this antigen are used in this report. 
RIP TEST

This was used as described by Gerloff and Watson (1967). Sera were tested in 2-fold dilutions ranging from 1:32 to 1: 1,024 without knowledge of CF results. Pooled serum from Montana children devoid of chlamydial antibody was included as a negative serum control in each test.

SN TEST

All sera were tested in mice for protective antibodies against lethal intracerebral challenge with LGV and TRIC Chlamydiae. Challenge strains included 4th yolk-sac passage of LGV, DC-009 strains, and 36th egg passage of the TRIC, LB-1 (TRIC/GB/MRC-1/G) strain originally isolated from the cervix of the mother of an infant with inclusion blennorrhoea (Jones, Collier, and Smith, 1959). The latter strain had been shown by Hurst and Reeve (1960) to be pathogenic for mice after intracerebral inoculation. Challenge seed was diluted in normal saline to contain six to twelve 50 per cent. mouse lethal doses $\left(M D_{50}\right)$ when incubated with a negative control serum for $18 \mathrm{hrs}$ at $4^{\circ} \mathrm{C}$. In the test, undiluted serum was mixed with an equal quantity of appropriately diluted challenge. After $18 \mathrm{hrs}$ ' incubation, each serum-challenge mixture was inoculated intracerebrally, using $0.03 \mathrm{ml}$. per dose, into groups of eighteen 21-day Rocky Mountain Laboratory mice. Each test included three negative control and fifteen test sera given to a total of 324 mice. A serum was considered to neutralize if the mouse survival rate for 14 days was significantly $(P<0.01)$ greater than the mean rate for all eighteen sera in the test.

\section{Results}

PRIMARY ISOLATION

Chlamydiae were detected in 21 of the 107 participants and 22 of the 117 specimens tested by one or both procedures.

21 of 103 specimens in irradiated cell culture and six of 81 specimens in embryonated eggs were positive. Of 67 specimens tested in both systems, five were positive in both and eleven were positive only in cell culture. Thus, overall, cell culture was the more sensitive procedure.

When the clinical source of specimens was considered (Table I), cell culture was particularly more effective than egg inoculation for demonstrating Chlamydiae from NGU and PGU cases. Only one of ten urethral specimens from these patients which were positive in cell culture was also positive in eggs.

Four of ten specimens from eight typical LGV cases were positive. Chlamydiae were recovered by both procedures from an inguinal bubo of one patient and a perirectal abscess of another. Aspirate from a bubo of a third patient was positive in cell culture but negative in eggs. However, Chlamydiae were recovered in eggs from a urethral specimen from this individual, which was not tested in cell culture. He had burning on urination but no urethral discharge.

Chlamydiae were detected in only one of eleven specimens from eight questionable cases of LGV. This was a urethral specimen, positive only in cell culture. The patient had persistent urethral discharge after treatment for gonorrhoea, accompanied by a nonfluctuant inguinal lymphadenopathy.

Chlamydiae were not isolated from five sexual contacts of LGV cases but they were recovered by both procedures from two of nine cervical specimens from nine NGU contacts.

Chlamydiae were also demonstrated by cell culture in five of 32 urethral specimens from 32 cases of gonorrhoea. These specimens were not tested in eggs.

The time relationship to the onset of the illness did not appear to be an important consideration in the

TABLE I Primary isolation of Chlamydiae in irradiated McCoy cells and embryonated eggs, by clinical category

\begin{tabular}{|c|c|c|c|c|c|c|c|}
\hline \multirow{4}{*}{ Clinical category ${ }^{\star}$} & \multicolumn{7}{|c|}{ Specimens tested in } \\
\hline & \multicolumn{4}{|c|}{ Cells and eggs } & \multirow{3}{*}{ Cells only $\dagger$} & \multirow{3}{*}{ Eggs only $\dagger$} & \multirow{3}{*}{ Total $\uparrow$} \\
\hline & \multirow[b]{2}{*}{ Total } & \multicolumn{3}{|c|}{ Positive in } & & & \\
\hline & & Both & Cells only & Neither & & & \\
\hline $\begin{array}{l}\text { LGV (typical) } \\
\text { LGV (questionable) } \\
\text { LGV contacts }\end{array}$ & $\begin{array}{l}8 \\
4 \\
5\end{array}$ & $\begin{array}{l}2 \\
0 \\
0\end{array}$ & $\begin{array}{l}1 \\
1 \\
0\end{array}$ & $\begin{array}{l}5 \\
3 \\
5\end{array}$ & $\bar{z}$ & $\begin{array}{l}1 / 2 \\
0 / 7 \\
0 / 4\end{array}$ & $\begin{array}{l}4 / 10 \\
1 / 11 \\
0 / 9\end{array}$ \\
\hline $\begin{array}{l}\text { NGU } \\
\text { NGU contacts }\end{array}$ & $\begin{array}{r}31 \\
8 \\
\end{array}$ & $\begin{array}{l}1 \\
2\end{array}$ & $\begin{array}{l}7 \\
0\end{array}$ & $\begin{array}{c}23 \\
6\end{array}$ & $\begin{array}{l}0 / 4 \\
0 / 1\end{array}$ & 二 & $\begin{array}{l}8 / 35 \\
2 / 9\end{array}$ \\
\hline PGU & 10 & 0 & 2 & 8 & - & $0 / 1$ & $2 / 11$ \\
\hline Gonorrhoea & 1 & 0 & 0 & 1 & $5 / 31$ & - & $5 / 32$ \\
\hline
\end{tabular}

* Isolation was not attempted from patients with syphilis

$\dagger$ Number of specimens positive/number of specimens tested 
isolation result; specimens found to be positive were collected no earlier during the course of the illness than those found to be negative.

\section{SEROLOGY}

Blood samples were obtained from 153 participants. Only 32 per cent. of patients with LGV, but nearly 90 per cent. of those with NGU, PGU, and gonorrhoea had the first sample taken one week or less after the onset of symptoms. Follow-up blood specimens were obtained from 56 participants 2 to 4 weeks (average 19 days) after the initial visit and the beginning of treatment.

\section{CF RESULTS}

51 participants (33 per cent.) had CF antibodies in titres ranging from $1: 8$ to $1: 128$ during the first visit. The prevalence and average titres of antibody were definitely higher in 'typical LGV' patients than in other clinical groups (Table II). On the other hand, prevalence and levels of antibody in NGU cases were similar to those in cases of PGU and gonorrhoea, and were, if anything, slightly lower than those in LGV and NGU contacts and in cases of syphilis. The occurrence and titres of antibody in Chlamydiaepositive cases did not differ from those in negative cases.

Serum pairs were tested from cases in all clinical groups except syphilis. 45 participants showed no change in CF titre. Ten had a 2 -fold rise or fall in titre. In only one case did the sera show significant change; this was a man with NGU in whom the serum taken on the second day of his illness was devoid of antibody but a specimen taken 2 weeks later had a titre of $1: 64$. Chlamydiae were not isolated from his urethra.

\section{RIP RESULTS}

Most initial sera (89 per cent.) were reactive in the RIP test in titres ranging from $1: 32$ to $>1: 1,024$. By

TABLE II Chlamydial group complement-fixing (CF) antibody titres in acute-phase (first) sera, by clinical category

\begin{tabular}{|c|c|c|c|c|c|c|c|c|c|}
\hline \multirow[t]{2}{*}{ Clinical category } & \multirow[t]{2}{*}{ Sera tested } & \multicolumn{6}{|c|}{ Reciprocal of CF titre $\dagger$} & \multirow[t]{2}{*}{ Per cent. $\geqslant 8$} & \multirow[t]{2}{*}{ Mean+ } \\
\hline & & $<8$ & 8 & 16 & 32 & 64 & 128 & & \\
\hline $\begin{array}{l}\text { LGV (typical) } \\
\text { LGV (questionable) } \\
\text { LGV contacts }\end{array}$ & $\begin{array}{r}12 \\
9 \\
6\end{array}$ & $\begin{array}{l}2 \\
6^{1} \\
2\end{array}$ & $\begin{array}{l}1 \\
2 \\
1\end{array}$ & $\frac{1^{1}}{2}$ & $\frac{3^{1}}{1}$ & $\frac{3^{1}}{-}$ & $\begin{array}{l}2 \\
1 \\
-\end{array}$ & $\begin{array}{l}83 \\
33 \\
67\end{array}$ & $\begin{array}{l}42 \\
20 \\
16\end{array}$ \\
\hline $\begin{array}{l}\text { NGU } \\
\text { NGU contacts }\end{array}$ & $\begin{array}{r}35 \\
9\end{array}$ & $\begin{array}{c}27^{7} \\
6\end{array}$ & $\begin{array}{l}7^{1} \\
1^{1}\end{array}$ & 1 & $\overline{2^{1}}$ & - & - & $\begin{array}{l}23 \\
33\end{array}$ & $\begin{array}{r}9 \\
20\end{array}$ \\
\hline PGU & 11 & $7^{1}$ & $3^{1}$ & 1 & - & - & 一 & 36 & 10 \\
\hline Gonorrhoea & 58 & $46^{4}$ & $7^{1}$ & 3 & 2 & - & 一 & 21 & 12 \\
\hline Syphilis & 13 & 6 & 3 & 1 & 2 & - & 1 & 54 & 20 \\
\hline
\end{tabular}

tSuperior numters indicate sera from Chlamydia-positive cases

$¥$ Geometric mean of titre $\geqslant 8$

TABLE III Chlamydial group radioisotope-precipitating (RIP) antibody titres in acute-phase(first) sera, by clinical category

\begin{tabular}{|c|c|c|c|c|c|c|c|c|c|c|c|}
\hline \multirow[t]{2}{*}{ Clinical category } & \multirow[t]{2}{*}{ Sera tested } & \multicolumn{8}{|c|}{ Reciprocal of RIP titre $\dagger$} & \multirow{2}{*}{ Per cent. $\geqslant 32$} & \multirow[t]{2}{*}{ Mean $\ddagger$} \\
\hline & & $<32$ & 32 & 64 & 128 & 256 & 512 & 1,024 & $>1,024$ & & \\
\hline $\begin{array}{l}\text { LGV (typical) } \\
\text { LGV (questionable) } \\
\text { LGV contacts }\end{array}$ & $\begin{array}{r}12 \\
9 \\
6\end{array}$ & $\frac{-}{1}$ & $\frac{1}{-}$ & $\overline{1}$ & $\begin{array}{l}- \\
4 \\
1\end{array}$ & $\begin{array}{l}1 \\
2 \\
-\end{array}$ & $\begin{array}{l}3^{2} \\
1 \\
-\end{array}$ & $\frac{5^{1}}{1}$ & $\begin{array}{l}2 \\
1 \\
2\end{array}$ & $\begin{array}{r}100 \\
100 \\
83\end{array}$ & $\begin{array}{l}644 \\
219 \\
512\end{array}$ \\
\hline $\begin{array}{l}\text { NGU } \\
\text { NGU contacts }\end{array}$ & $\begin{array}{r}35 \\
9\end{array}$ & $4^{1}$ & $\begin{array}{l}5^{2} \\
2\end{array}$ & $\begin{array}{c}15^{3} \\
1\end{array}$ & $\begin{array}{l}8^{1} \\
2\end{array}$ & $\begin{array}{l}3^{1} \\
1\end{array}$ & $\overline{2^{1}}$ & $\overline{1^{1}}$ & 二 & $\begin{array}{r}89 \\
100\end{array}$ & $\begin{array}{r}78 \\
161\end{array}$ \\
\hline$\overline{P G U}$ & 11 & 1 & 1 & $3^{1}$ & $5^{1}$ & - & 1 & - & - & 91 & $\overline{104}$ \\
\hline Gonorrhoea & 58 & 7 & 10 & $23^{3}$ & $9^{1}$ & $5^{1}$ & 2 & 1 & 1 & 88 & 85 \\
\hline Syphilis & $\overline{13}$ & 4 & 1 & 2 & - & 2 & 3 & - & 1 & 69 & 237 \\
\hline
\end{tabular}

† Superior numbers indicate sera from Chlamydia-positive cases 
clinical category, the patterns of reaction resembled those in the CF tests (Table III). Cases of LGV and their contacts generally had very high titres, whereas other clinical groups, including cases of NGU, showed low to moderate levels of reactivity. As with the CF test, the RIP titres of Chlamydiae-positive patients were similar to those of the Chlamydiaenegative patients.

The NGU patient with a CF-antibody response was the only person who had significant change in RIP antibodies; the titre rose from $<1: 32$ to $1: 256$ during his illness. There was no change in 41 cases and fourteen others showed a 2-fold rise or fall.

Although the RIP test was approximately twenty times more sensitive than the CF test, there was excellent correlation between the two procedures. No RIP-negative serum had CF antibodies, and RIP titres were never less than 4-fold higher than CF titres.

\section{SN RESULTS}

Fifteen acute-phase sera from seven typical LGV cases, two sexual contacts of LGV patients, three patients with gonorrhoea, and three with syphilis, neutralized the DC-009 strain of LGV (Table IV). Isolation of Chlamydiae was attempted in six of these fifteen persons with neutralizing antibodies, and was successful in three, including two cases of LGV (one was the source of the challenge strain) and one of gonorrhoea.

Eight of 56 convalescent sera neutralized DC-009. Three were from cases of LGV with antibodies in the initial sera. The other five were from initially negative cases: one LGV contact, one case of NGU, two NGU contacts, and one case of gonorrhoea. Chlamydiae had been recovered from the first serum in three cases in which sero-conversion occurred. In no case with initial serum-neutralizing activity was there a reversion to negative.

Because antigenic differences between LGV and TRIC strains could account for the greater neutralizing activity against $\mathrm{DC}-009$ in cases of $\mathrm{LGV}$, sera were also tested against the TRIC, LB-1 strain. Of the total of 204 sera, sixteen neutralized both strains, six only DC-009, and six only LB-1; 176 were nonreactive. The mouse survival rates with individual sera after LB-1 challenge directly correlated with those after DC-009. Thus, sera with strong protection against DC-009 were also highly protective against LB-1. Conversely, those poorly reactive against LGV were also poorly reactive against the TRIC strain. These findings suggest that there are no important immunological differences between LGV, DC-009, and TRIC, LB-1 strains.

$\mathrm{SN}$ results correlated with CF results. Only three (2 per cent.) of 144 sera without CF antibodies neutralized LGV. In contrast, twenty (30 per cent. of 66 sera with CF antibodies also had neutralizing activity. Furthermore, in sera with $\mathrm{CF}$ antibodies, the rise of titre was directly related to the frequency of neutralization and mouse survival.

As expected, there was also a quantitative correlation between serum neutralization and RIP antibody levels, but only when RIP titres exceeded $1: 128$ (Table V). Only three (2 per cent.) of 150 sera

TABLE IV Acute-phase (first) serum neutralization ( $S N$ ) of LGV challenge (DC-009 strain), by clinical category

\begin{tabular}{|c|c|c|c|c|c|c|}
\hline \multirow{4}{*}{ Clinical category } & \multicolumn{6}{|c|}{$S N$ results $\dagger$} \\
\hline & \multicolumn{3}{|l|}{ Sera } & \multicolumn{3}{|l|}{ Mice } \\
\hline & \multicolumn{3}{|l|}{ Positive } & \multicolumn{3}{|l|}{ Survivors } \\
\hline & Tested & No. & Per cent. & Challenged & No. & Per cent. \\
\hline $\begin{array}{l}\text { LGV (typical) } \\
\text { LGV (questionable) } \\
\text { LGV contacts }\end{array}$ & $\begin{array}{r}12 \\
9 \\
6\end{array}$ & $\begin{array}{l}7 \\
0 \\
2\end{array}$ & $\begin{array}{r}58 \\
0 \\
33\end{array}$ & $\begin{array}{l}216 \\
162 \\
108\end{array}$ & $\begin{array}{r}79 \\
7 \\
29\end{array}$ & $\begin{array}{r}36 \cdot 6 \\
4 \cdot 3 \\
26 \cdot 9\end{array}$ \\
\hline $\begin{array}{l}\text { NGU } \\
\text { NGU contacts }\end{array}$ & $\begin{array}{r}35 \\
9\end{array}$ & $\begin{array}{l}0 \\
0\end{array}$ & $\begin{array}{l}0 \\
0\end{array}$ & $\begin{array}{l}630 \\
162\end{array}$ & $\begin{array}{r}38 \\
8\end{array}$ & $\begin{array}{l}6.0 \\
4 \cdot 9\end{array}$ \\
\hline PGU & 11 & ) & 0 & 197 & 7 & $3 \cdot 6$ \\
\hline Gonorrhoea & 58 & 3 & 5 & 1,044 & 33 & $3 \cdot 2$ \\
\hline Syphilis & 13 & 3 & 23 & 234 & 27 & $11 \cdot 5$ \\
\hline Controls & 42 & 0 & 0 & 756 & 27 & $3 \cdot 6$ \\
\hline
\end{tabular}

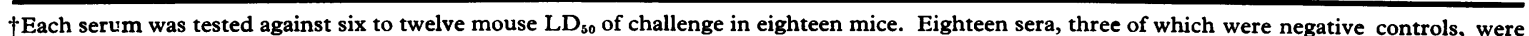

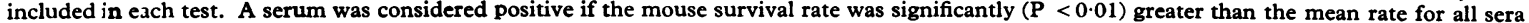
ni the test. 
TABLE V Correlation of LGV (DC-009 strain) serum neutralizing ( $S N$ ) activity to chlamydial group radioisotope-precipitating $(R I P)$ antibody titres in all sera

\begin{tabular}{|c|c|c|c|c|c|c|}
\hline \multirow{4}{*}{$R I P$ titre ${ }^{*}$} & \multicolumn{6}{|c|}{$S N$ results $\dagger$} \\
\hline & \multicolumn{3}{|l|}{ Sera } & \multicolumn{3}{|l|}{ Mice } \\
\hline & \multicolumn{3}{|c|}{ Positive } & \multicolumn{3}{|l|}{ Survivors } \\
\hline & Tested & No. & Per cent. & Challenged & No. & Per cent. \\
\hline $\begin{array}{r}<32 \\
32 \\
64 \\
128 \\
256 \\
512 \\
1,024 \\
>1,024\end{array}$ & $\begin{array}{r}21 \\
32 \\
57 \\
40 \\
23 \\
17 \\
12 \\
8\end{array}$ & $\begin{array}{l}1 \\
0 \\
2 \\
0 \\
3 \\
5 \\
7 \\
5\end{array}$ & $\begin{array}{r}5 \\
0 \\
4 \\
0 \\
13 \\
29 \\
58 \\
63\end{array}$ & $\begin{array}{r}378 \\
576 \\
1,025 \\
719 \\
414 \\
306 \\
216 \\
144\end{array}$ & $\begin{array}{l}12 \\
20 \\
28 \\
33 \\
47 \\
42 \\
74 \\
55\end{array}$ & $\begin{array}{r}3.2 \\
3.5 \\
2.7 \\
4.6 \\
11.4 \\
13.7 \\
34.4 \\
38 \cdot 2\end{array}$ \\
\hline
\end{tabular}

* Reciprocals

†See footnote to Table IV

with titres $\leq 1: 128$ protected, whereas twenty (33 per cent.) of sixty sera with higher titres neutralized LGV. This pattern was also reflected in mouse survival rates.

\section{CHARACTERISTICS OF ISOLATES}

The six strains of Chlamydiae isolated in embryonated eggs were characterized (Table VI). The LGV strains were clearly distinguished from NGU isolates by their greater pathogenicity both for chick embryos and mice. They were recovered on first or second egg passage and two of the three were re-isolited in mouse brain from the original specimen. They were fully established in eggs by the fourth passage producing low ratios of 50 per cent. infectious dose $\left(I_{50}\right)$ to 50 per cent. lethal dose $\left(\mathrm{LD}_{50}\right)$ for chick embryos. Low dilutions of infected yolk sac were lethal for weanling mice when inoculated intracerebrally and intranasally but not when given by other routes.

The NGU strains likewise were recovered on first or second egg passage. However, after the fourth passage, they were only weakly virulent for chick $\vec{\nabla}$ embryos, as reflected in high $\mathrm{ID}_{50} / \mathrm{LD}_{50}$ ratios. High concentrations of infected yolk sac caused toxic deaths in mice inoculated intravenously, but in dosages equivalent to those for LGV isolates, the NGU isolates caused neither death nor signs of illne in mice by other routes of inoculation.

\section{DISCUSSION}

Three additional strains of Chlamydiae, one of cervical $\stackrel{2}{\stackrel{2}{ฉ}}$ origin, have been recovered from LGV patients in $\overrightarrow{\vec{P}}$ D.C. since this study was completed. These, as well as the three strains isolated during the study, are uniform in characteristics of pathogenicity and resemble the classical JH strain of LGV (Rake and Jones, 1942) which has a laboratory history of 30 years. Their homogeneity is not unexpected, since they were derived from a relatively circumscribed population group in contrast to the heterogeneous strains recovered by Schachter and Meyer (1969) from diverse sources.

This study showed that Chlamydiae with TRIC-like

TABLE VI Some characteristics of Chlamydiae isolated in embryonated eggs

\begin{tabular}{|c|c|c|c|c|c|c|c|c|c|}
\hline \multirow{3}{*}{$\begin{array}{l}D C \\
\text { No. }\end{array}$} & \multirow{3}{*}{ Clinical category } & \multirow{3}{*}{ Source } & \multicolumn{7}{|c|}{ Pathogenicity* } \\
\hline & & & \multirow{2}{*}{$\begin{array}{l}\text { Passage } \\
\text { level }\end{array}$} & \multicolumn{2}{|c|}{ Embryo $\left(\log _{10}\right)$} & \multicolumn{4}{|c|}{ Mouse $L D_{50}\left(\log _{10}\right)$} \\
\hline & & & & $I D_{50}$ & $L D_{50}$ & i.c. & i.p. & $i . v$. & $i . n$. \\
\hline $\begin{array}{l}001 \\
009 \\
036\end{array}$ & $\begin{array}{l}\text { LGV } \\
\text { LGV } \\
\text { LGV }\end{array}$ & $\begin{array}{l}\text { Perirectal abscess } \\
\text { Bubo-pus } \\
\text { Urethra }\end{array}$ & $\begin{array}{l}5 \\
4 \\
6\end{array}$ & $\begin{array}{l}5 \cdot 7 \\
5 \cdot 9 \\
5 \cdot 9\end{array}$ & $\begin{array}{l}5 \cdot 2 \\
5 \cdot 9 \\
5 \cdot 1\end{array}$ & $\begin{array}{l}3 \cdot 1 \\
3 \cdot 5 \\
3 \cdot 1\end{array}$ & $\begin{array}{l}<0.6 \\
<0.6 \\
<0.6\end{array}$ & $\begin{array}{l}<0.6 \\
<0.6 \\
<0.6\end{array}$ & $\begin{array}{l}2 \cdot 2 \\
2 \cdot 2 \\
1 \cdot 8\end{array}$ \\
\hline $\begin{array}{l}044 \\
049 \\
055\end{array}$ & $\begin{array}{l}\text { NGU contact } \\
\text { NGU } \\
\text { NGU contact }\end{array}$ & $\begin{array}{l}\text { Cervix } \\
\text { Urethra } \\
\text { Cervix }\end{array}$ & $\begin{array}{l}4 \\
4 \\
5\end{array}$ & $\begin{array}{l}6 \cdot 3 \\
5 \cdot 6 \\
5 \cdot 9\end{array}$ & $\begin{array}{l}3 \cdot 2 \\
3 \cdot 2 \\
4 \cdot 1\end{array}$ & $\begin{array}{l}<1.8 \\
<1.8 \\
<1.8\end{array}$ & $\begin{array}{l}<0.6 \\
<0.6 \\
<0.6\end{array}$ & $\begin{array}{l}1 \cdot 1 \\
0 \cdot 7 \\
0 \cdot 7\end{array}$ & $\begin{array}{l}<1.8 \\
<1.8 \\
<1.8\end{array}$ \\
\hline
\end{tabular}

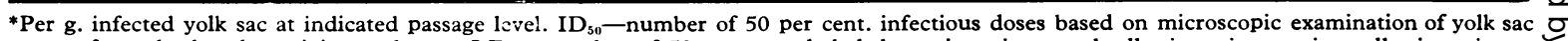

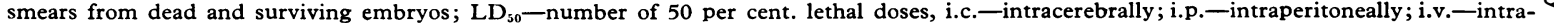
venously; i.n.-intranasally. Titrations based on groups of ten eggs and twelve mice per dilution of infected yolk sac. 
characteristics of pathogenicity were also circulating in this population group, but we have not examined enough isolates to conclude that TRIC and LGV strains can be differentiated merely by their association with particular clinical syndromes. However, it is noteworthy that an LGV strain was recovered from a urethra and another from a cervix, both common sites of TRIC infection. Consequently, isolation of a strain of Chlamydiae from these areas is not necessarily an indication that the isolate will be a TRIC strain.

LGV continues to be a significant health problem in Washington, D.C. Twelve clinical cases were recognized during only 2 months of study in one clinic. All patients were residents of D.C., who voluntarily sought treatment. It is noteworthy that all were males without obvious common sources of infection. Clinical cases among women were not seen, either because they were unrecognized or because infection was inapparent. Chlamydiae were not isolated from six sexual contacts of LGV cases, but three had high antibody titres indicating recent infection. In these consorts the clinical manifestations were not sufficiently pronounced to prompt them to seek medical attention had they not been aware of the disease in their sexual partners.

This study provided little additional information in support of an aetiological relationship between TRIC Chlamydiae and clinical manifestations of urethritis, even though sensitive isolation and serological procedures were used. One of every five patients with NGU or PGU was shown by irradiated cell culture to be infected with Chlamydiae. An even higher isolation rate might have resulted if curettes had been used. However, detection of Chlamydiae was not less frequent in cases of gonorrhoea, and an asymptomatic control group with a comparable level of sexual activity was not available for assessing the clinical relationship of TRIC Chlamydiae to NGU. Furthermore, the prevalence of positive serological reactions was no higher in cases of NGU than in cases of gonorrhoea and syphilis, and a rise in titre coinciding with illness could be demonstrated in only one instance. Chlamydial infections are undoubtedly common in this population group, but the appearance of stable antibody titres so early in the course of illness does not support the notion that NGU and PGU are clinical manifestations of primary infection.

Irradiated McCoy cells were better than embryonated eggs for recovery of TRIC Chlamydiae. This finding is consistent with results reported elsewhere (Gordon and others, 1969) comparing these two procedures. Usually, many inclusions $(4,000$ to $10,000 / \mathrm{ml}$. of specimen) were found on first- passage cell culture of specimens positive in embryonated eggs in contrast to few inclusions (30 to 2,500 / $\mathrm{ml}$. of specimen) in cell cultures of specimens negative in eggs. This suggests a quantitative difference in sensitivity of the two systems perhaps related to the effectiveness of delivery of infectious particles to the sites of replication. Centrifugation of elementary bodies on to monolayers is an important part of the cell culture procedure. However, differences in susceptibility of the two systems to variations in chlamydial strains must also be considered. The one NGU urethral strain isolated in eggs, initially produced only thirty inclusions $/ \mathrm{ml}$. of specimen on primary passage in cell culture.

The CF test is the most widely used serological procedure for the diagnosis of chlamydial infections, yet the specificity of low titres has always been questioned. The conformity of CF findings to those of the SN test suggests that CF reactions in this study resulted from chlamydial infection. Like the CF test, the RIP test is group reactive. It is a very sensitive procedure which has been thoroughly standardized in replicate tests and used in population groups with varying degrees of exposure to chlamydial infection, including children, fur-trappers, sheep-ranchers, trachoma patients (Gerloff and Watson, 1967), and Navy personnel (Gerloff, unpublished data). Titres of $1: 32$ or higher reflect binding of antigen which is considered significant on the basis of this experience. It is likely that most titres $\geq 1: 256$ in this study were chlamydial antigen-antibody reactions. There is no way of assessing whether this was also true of reactions ranging from $1: 32$ to $1: 128$. However, it is noteworthy that this population group was more reactive than any we have so far tested.

\section{Summary}

Isolation of lymphogranuloma venereum and urogenital trachoma-inclusion conjunctivitis Chlamydiae was attempted and serological responses to chlamydial infection were studied in a District of Columbia venereal disease clinic population. The isolation procedures included injection of bubo, urethral, and cervical specimens into embryonated chicken eggs and irradiated $\mathrm{McC}$ oy cell cultures. The serological procedures included the complement-fixation and radioisotope precipitation tests of single and paired sera for chlamydial-group antibodies and a mouse neutralization test for specific antibodies.

Ten of twelve typical clinical cases of lymphogranuloma venereum had high antibody titres, and Chlamydiae were isolated from the lesions of three.

Chlamydiae were demonstrated in ten of 47 cases of nongonococcal urethritis and postgonococcal urethritis, but serological titres were low and only one 
person had an antibody response coinciding with illness. A causal relationship of urethritis to chlamydial infection could not be established.

Chlamydiae were detected in five of 59 cases of gonorrhoea and antibody patterns were similar to those in nongonococcal urethritis and postgonococcal urethritis patients.

Three lymphogranuloma venereum and three nongonococcal urethritis contacts had high antibody titres indicative of recent chlamydial infection, and Chlam$y$ diae were isolated from two nongonococcal urethritis consorts.

Three strains from lymphogranuloma venereum patients had the characteristic pathogenicity of lymphogranuloma venereum Chlamydiae in embryonated eggs and laboratory mice. Three strains from nongonococcal urethritis patients or their contacts were less pathogenic than lymphogranuloma venereum strains in eggs and nonpathogenic in mice.

The authors are indebted to Dr. C. Wendell Freeman, Chief of the Venereal Disease Control Division, District of Columbia Department of Health, whose active interest made this study possible, and Mrs. Corine Wilson and staff of the Northwest Central Venereal Disease Clinic, District of Columbia Department of Health, for their assistance in collecting clinical information and laboratory specimens from study participants. They are also grateful for the excellent technical assistance of Mr. James Whitlock, Mrs. Gertrude Monk, Mr. Rex Watson, Mr. Richard Grays, and Mr. Byron Ward.

\section{References}

Al-Hussaini, M. K., Jones, B. R., and Dunlop, E. M. C. (1964) Brit. F. vener. Dis., 40, 25

Dunlop, E. M. C., Jones, B. R., and Al-Hussaini, M. K. (1964) Ibid., 40, 33

Gerloff, R. K., and Watson, R. O. (1967) Amer. F. Ophthal., 63, 1492

Gordon, F. B., Harper, I. A., Quan, A. L., Treharne, J. D., Dwyer, R. St. C., and Garland, J. A. (1969) f. infect. Dis., 120, 451

Greaves, A. B. (1963) Bull Wld Hlth Org., 29, 797

- and TAGgart, S. R. (1953) Amer. F. Syph., 37, 273

Hill, D. A., Philip, R. N., Greaves, A. B., and PURCell, R. H. In preparation.

Hilleman, M. R., and Nigg, C. (1948) f. Immunol., 59, 349

HURST, E. W., and ReEve, P. (1960) Nature (Lond.), 186, 336

Jones, B. R., Al-Hussaini, M. K., and Dunlop, E. M. C. (1964) Brit. F. vener. Dis., 40, 19.

- Collier, L. H., and SMITH, C. H. (1959), Lancet, 1, 902

Philip, R. N., Lackman, D. B., Frank, F. W., Morrison, J. D., Casper, E. A., and Greaves, A. B. (1967) Amer. f. Ophthal., 63, 1499
RAKE, G., and JoNEs, H. P. (1942), F. exp. Med., 75, 323

Schachter, J., and MeYeR, K. F. (1969), f. Bact., 99, 636

Stamp, J. T., McEwen, A. D., Watt, J. A. A., and NisBeT, D. I. (1950) Vet. Rec., 62, 251

Etude des chlamydiae chez des malades consultant dans une clinique vénéréologique et atteints de lymphogranulomatose vénérienne ou d'urétrites

\section{SOMMAIRE}

On a recherché les chlamydiae dans la lymphogranulomatose vénérienne et dans les affections uro-génitales à inclusions similaires à celles des inclusions de la conjonctivite trachomateuse; on a, en outre, dans une population d'une clinique vénéréologique du district de Columbia, étudié la sérologie vis à vis de l'infection créée par les chlamydiae. Le dispositif d'isolement comprenait l'injection dans des oeufs de poule embryonnés et dans des cultures de cellules McCoy irradiées, de matériel provenant de bubons, de l'urètre et du col utérin. Lê dispositif sérologique comprenait la fixation du come plément et les épreuves de précipitation radio-isotopiques pour des sérums isolés ou réunis par paires, vis à vis desanticorps du groupe chlamydial et une épreuve de neutalisation des anticorps spécifiques chez la souris.

Dix de 12 cas clinique typiques de LGV avaient un haut titre d'anticorps et les chlamydiae furent isolés des lésions dans 3 cas.

Les chlamydiae furent mis en évidence dans 10 cas sur 47 d'urétrites non gonococciques ou post-gonococciques, mais les titres sérologiques furent bas et une personne seulement donna une résponse immunologique en accord avec la maladie. Une relation de cause à effet entre l'urétrite et l'infection chlamydiale ne put pas être établie.

Les chlamydiae ont été trouvés dans 5 cas de gonococcie sur 59 , et les réponses immunologiques furent similaires à celles des malades atteints d'urétrite non gonococcique ou post-gonococcique.

Les contacts de 3 malades atteints de la lymphogranulomatose vénérienne et de 3 malades atteints d'urétrite non gonococcique avaient de hauts titres d'anticorps, indiquant une infection chlamydiale récente, et des chlamydiae furent isolés chez 2 des partenaires de sujets ayant une urétrite non gonococcique. Trois souches isolées chez des malades atteints de la lymphogranulomatose vénérienne avaient les caractères de pathogénicité des chlamydiae chez les oeufs embryonnés et les souris de laboratoire. Trois souches provenant de malades urétrite non gonococcique ou de leur contacts se montrèrent moins pathogènes que les souches de lymphogranulomatose vénérienne sur les oeufs, et non pathogènes pour les souris. 